\title{
NORPERM, the Norwegian Permafrost Database - a TSP NORWAY IPY legacy
}

\author{
H. Juliussen ${ }^{1, *}$, H. H. Christiansen ${ }^{1,2}$, G. S. Strand ${ }^{3}$, S. Iversen ${ }^{3}$, K. Midttømme ${ }^{3, * *}$, and J. S. Rønning ${ }^{3,4}$ \\ ${ }^{1}$ The University Centre in Svalbard, Longyearbyen, Svalbard, Norway \\ ${ }^{2}$ Department of Geosciences, University of Oslo, Oslo, Norway \\ ${ }^{3}$ Geological Survey of Norway, Trondheim, Norway \\ ${ }^{4}$ Norwegian University of Science and Technology, Trondheim, Norway \\ *now at: Department of Geography, University of Bergen, Bergen, Norway \\ ** now at: Norwegian Geotechnical Institute, Oslo/Trondheim, Norway
}

Received: 15 February 2010 - Published in Earth Syst. Sci. Data Discuss.: 23 February 2010

Revised: 10 September 2010 - Accepted: 21 September 2010 - Published: 8 October 2010

\begin{abstract}
NORPERM, the Norwegian Permafrost Database, was developed at the Geological Survey of Norway during the International Polar Year (IPY) 2007-2009 as the main data legacy of the IPY research project Permafrost Observatory Project: A Contribution to the Thermal State of Permafrost in Norway and Svalbard (TSP NORWAY). Its structural and technical design is described in this paper along with the ground temperature data infrastructure in Norway and Svalbard, focussing on the TSP NORWAY permafrost observatory installations in the North Scandinavian Permafrost Observatory and Nordenskiöld Land Permafrost Observatory, being the primary data providers of NORPERM. Further developments of the database, possibly towards a regional database for the Nordic area, are also discussed.

The purpose of NORPERM is to store ground temperature data safely and in a standard format for use in future research. The IPY data policy of open, free, full and timely release of IPY data is followed, and the borehole metadata description follows the Global Terrestrial Network for Permafrost (GTN-P) standard. NORPERM is purely a temperature database, and the data is stored in a relation database management system and made publically available online through a map-based graphical user interface. The datasets include temperature time series from various depths in boreholes and from the air, snow cover, ground-surface or upper ground layer recorded by miniature temperature data-loggers, and temperature profiles with depth in boreholes obtained by occasional manual logging. All the temperature data from the TSP NORWAY research project is included in the database, totalling 32 temperature time series from boreholes, 98 time series of micrometeorological temperature conditions, and 6 temperature depth profiles obtained by manual logging in boreholes. The database content will gradually increase as data from previous and future projects are added. Links to near real-time permafrost temperatures, obtained by GSM data transfer, is also provided through the user interface.
\end{abstract}

\section{Introduction}

Permafrost is ground (soil or rock and included ice and organic material) that remains at or below $0{ }^{\circ} \mathrm{C}$ for at least two consecutive years (van Everdingen, 1998). Permafrost is widespread; it underlies approximately $23.9 \%$ of the Earth's exposed land area of the Northern Hemisphere (Zhang et al., 1999). And the temperature of permafrost may serve

Correspondence to: $\mathrm{H}$. Juliussen

(havard.juliussen@geog.uib.no) as a useful indicator of climate change (Lachenbruch et al., 1988). As a result, permafrost was identified as one of six cryospheric indicators of climate change by the Global Climate Observing System (GCOS) through the Global Terrestrial Observation System (GTOS) (Burgess et al., 2000). The Global Terrestrial Network for Permafrost (GTN-P) of the GCOS/GTOS is responsible for the international coordination and management of permafrost temperature data and active layer depths (Burgess et al., 2000). 
Present public and scientific interest in permafrost generates from the possible geomorphic response of permafrost thaw following climate warming, including land subsidence and slope processes (Nelson et al., 2001; Gruber and Haeberli, 2007). Permafrost thaw will also most likely increase the release of old carbon from the tundra to the atmosphere (Schuur et al., 2009), which will further enhance global warming. Knowledge of the thermal state of permafrost is thus of great importance to evaluate its vulnerability to thaw.

In the last three to four decades, permafrost temperatures have increased in large areas of the Arctic (Pavlov, 1994; Osterkamp and Romanovsky, 1999; Smith et al., 2005; Jorgenson et al., 2006; Osterkamp, 2007; Isaksen et al., 2007; Harris et al., 2009). The instrumented sites are, however, unevenly distributed and large areas are not represented, and a need for a global permafrost temperature monitoring network was realized by the International Permafrost Association (IPA) who coordinated the International Polar Year (IPY) 2007-2009 research project Permafrost Observatory Project: A Contribution to the Thermal State of Permafrost (TSP). The main aims of the TSP project were to obtain a snapshot of permafrost temperatures during the IPY as a baseline for future changes (i.e. next IPY) that spatially covers the world's permafrost regions, and to significantly expand the network of boreholes for improved detection of future changes in the permafrost thermal state (Brown and Christiansen, 2006). In the national TSP projects, permafrost observatories were established with ground temperature recordings in boreholes, either as occasional logging or continuous monitoring, and some sites also have temperature monitoring in the air, snow cover, at the ground surface and/or in the upper ground to resolve climate-permafrost relationships. Recordings of the active layer thickness for the Circumpolar Active Layer Monitoring (CALM) network (Brown et al., 2000) were also included. The objective is to maintain the observatories also after the IPY, as International Network of Permafrost Observatories, to provide long-term data series. These series will contribute to global observation programmes such as the Sustaining Arctic Observing Networks (SAON) and the Pan-Antarctic Observing System (PantOS).

The Norwegian contribution to TSP, the Permafrost $\mathrm{Ob}$ servatory Project: A Contribution to the Thermal State of Permafrost in Norway and Svalbard (TSP NORWAY), has established permafrost observatories in Troms and Finnmark, the two northernmost counties of Norway, and in central and western Svalbard (Christiansen et al., 2010). These contain 32 boreholes and 98 sites with miniature temperature dataloggers (MTDs) for continuous monitoring of micrometeorological temperature conditions (see Table 1). The considerable amount of data acquired are handled according to the IPY data policy (International Polar Year Data and Information Service - IPYDIS, http://ipydis.org), stating that data collected under the auspices of IPY-projects should be stored in secure repositories and made openly, freely and fully available on the shortest feasible timescale (http://ipydis.org).
Table 1. All NORPERM study areas in the North Scandinavian and Nordenskiöld Land Permafrost Observatories, including the number of boreholes and miniature temperature data-loggers (MTDs). Boreholes with continuous temperature monitoring and boreholes with manual temperature logging are listed separately.

\begin{tabular}{|c|c|c|c|}
\hline Study Areas & $\begin{array}{l}\text { No. of boreholes } \\
\text { with monitoring }\end{array}$ & $\begin{array}{l}\text { No. of boreholes } \\
\text { with logging }\end{array}$ & MTDs \\
\hline \multicolumn{4}{|c|}{ North Scandinavian Permafrost Observatory } \\
\hline Kistefjellet & 1 & - & 2 \\
\hline Njunis & - & - & 4 \\
\hline Lavkavagge & 3 & - & - \\
\hline Nordnes & 3 & - & 18 \\
\hline Kåfjord-Ryodasvarri & - & - & 4 \\
\hline Guolasjavri & 3 & - & - \\
\hline Trolltinden & 1 & - & - \\
\hline Abojavri & 2 & - & 1 \\
\hline Bidjovagge & - & 2 & 1 \\
\hline Kautokeino & - & - & 1 \\
\hline Suolovuopmi & - & - & 1 \\
\hline Sihccajavri & - & - & 1 \\
\hline Cuovdattmohkki & - & - & 3 \\
\hline Karasjok/Iškoras & 2 & - & 7 \\
\hline Tana/Rustefjelbma & - & 1 & 2 \\
\hline Karlebotn & - & - & 1 \\
\hline TOTAL & 15 & 3 & 46 \\
\hline \multicolumn{4}{|c|}{ Nordenskiöld Land Permafrost Observatory } \\
\hline Kapp Linnè & 4 & - & 10 \\
\hline Advent- and Longyeardalen & 10 & 3 & 42 \\
\hline Ny-Ålesund & 1 & - & - \\
\hline Reindalen-Lunckefjell & 1 & - & - \\
\hline Svea & 1 & - & - \\
\hline TOTAL & 17 & 3 & 52 \\
\hline TOTAL, both observatories & 32 & 6 & 98 \\
\hline \multicolumn{4}{|c|}{ Southern Norway (school module) } \\
\hline Åsvang & - & - & 1 \\
\hline Malvik & - & - & 1 \\
\hline Gausdal & - & - & 1 \\
\hline TOTAL & - & - & 3 \\
\hline
\end{tabular}

The collected temperature data was either included in existing database systems such as e.g. the Cooperative Arctic Data and Information Service (CADIS) database of the Arctic Observing Network (AON-CADIS) used by the USRussian TSP project (http://www.aoncadis.org/projects), or a new database had to be developed to accommodate all the ground thermal data collected, such as done in the TSP NORWAY project by establishing the Norwegian Permafrost Database (NORPERM). The GTN-P acts as the international TSP metadatabase (Burgess et al., 2000). NORPERM was technically developed by the Geological Survey of Norway (NGU), in cooperation with the TSP NORWAY scientists, and forms part of the national borehole database at the Geological Survey of Norway. It is purely a temperature database containing primarily datasets on ground temperature, but also on air temperature and snow temperature where recorded together with ground temperature. 
The aim of this paper is to present the main data legacy of the TSP NORWAY project; the NORPERM database and its structural and technical design. We also give an overview of the pre-IPY and the IPY permafrost data infrastructure in Norway and Svalbard, with focus on the two TSP NORWAY permafrost observatories as the main data sources. Potential future developments of NORPERM are discussed towards the end of the paper.

\section{Infrastructure of permafrost temperature data in Norway and Svalbard}

While permafrost in Svalbard is continuous except beneath large glaciers, widespread permafrost in Norway is restricted to the mountain areas (Brown et al., 2001; Etzelmüller et al., 2003; Humlum et al., 2003; Harris et al., 2009). Sporadic permafrost occurs in palsas down to sea level in Northern Norway (Åhman, 1977). Christiansen et al. (2010) gives an overview of the thermal state of permafrost in the Nordic region during IPY, showing that the mean temperature in the upper part of the permafrost in the Norwegian mountains is above $-1{ }^{\circ} \mathrm{C}$ except in the highest-lying locations, while in Svalbard it is in the range -2 to $-6^{\circ} \mathrm{C}$.

\subsection{Pre-IPY permafrost data}

Before the IPY 2007-2009, direct thermal monitoring of permafrost existed only at Juvvasshøe and Dovrefjell in southern Norway, two sites in Troms, Northern Norway, and Janssonhaugen and Adventdalen in central Svalbard (Christiansen et al., 2010). The Permafrost and Climate in Europe (PACE) project initiated in 1998-2000 thermal monitoring at Juvvasshøe and Janssonhaugen down to 129 and $100 \mathrm{~m}$ depth (Isaksen et al., 2001; Harris et al., 2009). Ground temperature has been monitored since 2001 in an altitudinal transect of 11 shallow boreholes $(9-10 \mathrm{~m})$ across the altitudinal permafrost transition zone in Dovrefjell, southern Norway (Sollid et al., 2003). A long-term monitoring programme of permafrost and climate and its potential influence on unstable rock slopes was initiated in 2001 with one borehole at Dalsnibba in southern Norway and two in Northern Norway at Guolasjavri and Trolltinden (Isaksen et al., 2004), the latter two being included in TSP NORWAY. In addition, numerous near-ground-surface temperature series exists from permafrost mapping projects in different mountain areas (e.g. Isaksen et al., 2002; Heggem et al., 2005; Juliussen and Humlum, 2007; Farbrot et al., 2008; Isaksen et al., 2008) and periglacial process studies (e.g. Christiansen, 2005; Juliussen and Humlum, 2008).

Before the IPY the focus had mostly been on the mountains of southern Norway, but during the IPY an increased focus on the northern areas of Norway emerged to fill this gap (Farbrot et al., 2008; Isaksen et al., 2008; Christiansen et al., 2010).

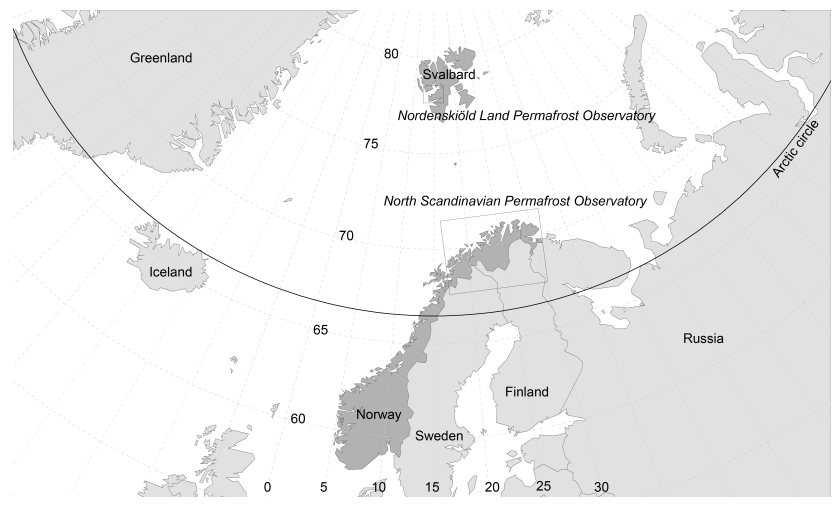

Figure 1. Location of the North Scandinavian Permafrost Observatory (cf. Fig. 2) and the Nordenskiöld Land Permafrost Observatory (cf. Fig. 3) in the North-Atlantic Region. The numbers indicate the latitude and longitude in degrees $\mathrm{N}$ and $\mathrm{E}$, respectively.

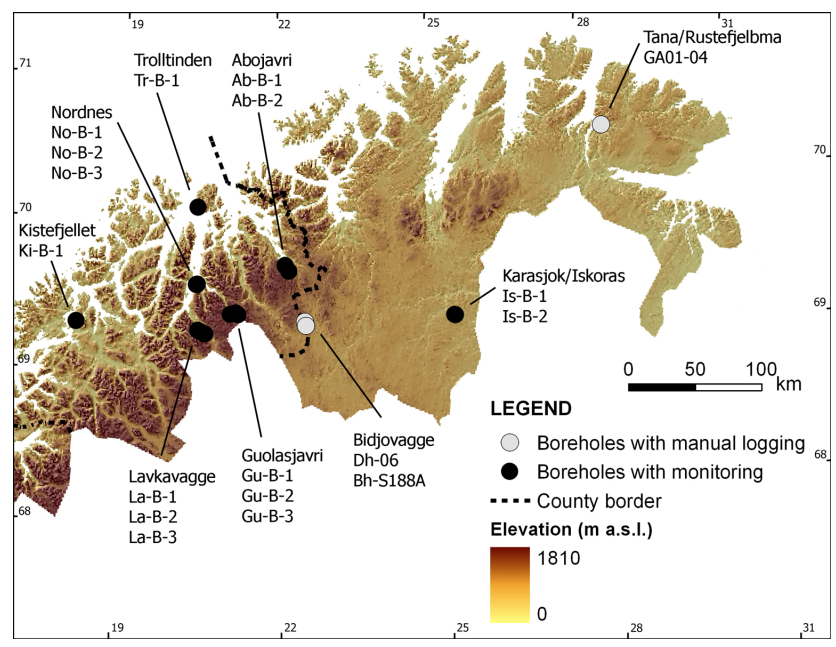

Figure 2. The North Scandinavian Permafrost Observatory with the position of the boreholes indicated. The borehole IDs refer to Table 2.

\subsection{Permafrost observatory design}

During the IPY, two permafrost observatories were established in the North-Atlantic region by the TSP NORWAY project (Fig. 1); the North Scandinavian Permafrost Observatory, in Norway covering the counties of Troms and Finnmark (Fig. 2), and the Nordenskiöld Land Permafrost Observatory in central Svalbard (Fig. 3). The observatories cover the climatic gradients from the maritime west coasts of Northern Norway and Svalbard to the moderately continental Finnmarksvidda of Northern Norway and the Adventdalen area in Svalbard. Within the observatories, temperature measurement sites are clustered into 16 study areas in Northern Norway and seven in Svalbard (Table 1). The study areas were distributed at key locations along the climatic gradients to obtain a spatially distributed snapshot of 


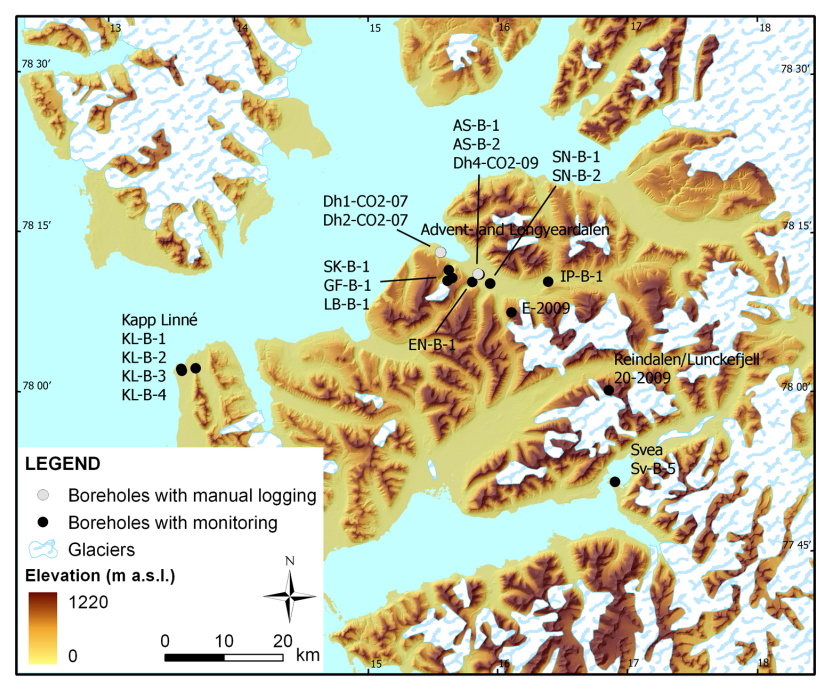

Figure 3. The Nordensköld Land Permafrost Observatory in Svalbard with the position of the boreholes indicated. The Ny-Ålesund borehole is located outside the map. The borehole IDs refer to Table 2 .

ground temperatures. In Northern Norway, the Kistefjellet mountain in the west and the Iškoras mountain in continental Finnmarksvidda in the east represent the range in continentality (Fig. 2). In Svalbard, the continentality range is represented by Kapp Linnè at the most martime part of the west coast to the Advent- and Longyeardalen area in Svalbard (Fig. 3). In some study areas the number and location of the measurement sites have been selected to quantify the spatial variability in microclimate due to differences in snow cover, vegetation or ground-surface material within the study area. Monitoring continues at most of the sites after the IPY for future assessment of long-term trends in ground temperatures.

\subsection{IPY ground thermal instrumentation}

The measurements include continuous monitoring of ground temperatures in boreholes, occasional manual temperature logging in boreholes and continuous temperature monitoring in the air, snow cover, at the ground surface or in the upper ground layer using miniature temperature data-loggers (MTDs) (Fig. 4).

Eight holes were drilled and instrumented for temperature monitoring in Northern Norway in autumn 2007, and additional five holes were established in 2008 (Table 2). In addition, two existing boreholes (Isaksen et al., 2004) were re-instrumented for continuous monitoring (Table 2). Thus, there were in total 15 TSP boreholes with continuous temperature monitoring in Northern Norway during the IPY (Table 1).

In Svalbard, 12 holes were drilled in spring 2008 and instrumented in summer and autumn 2008 (Tables 1 and 2)
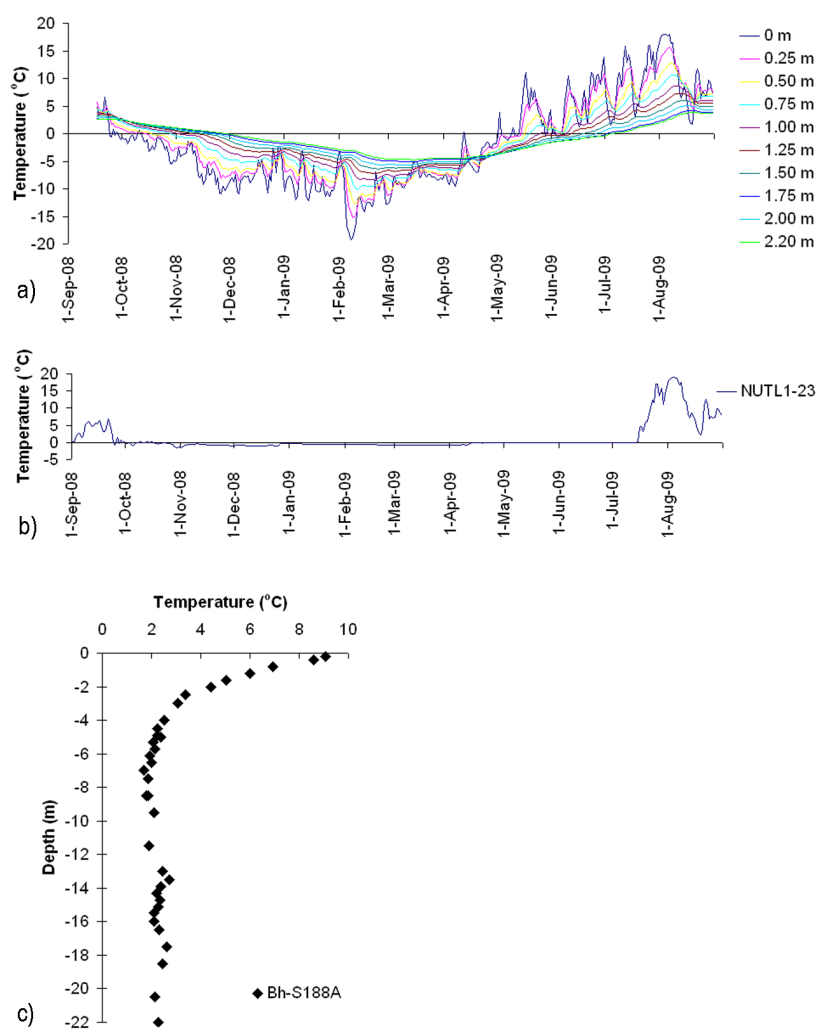

Figure 4. Examples of the three different data types collected as part of the TSP NORWAY research project, all collected in the North Scandinavian Permafrost Observatory. (a) temperature timeseries from monitoring in the borehole NO-B-3 in the Nordnes study area, (b) temperature time-series from micrometeorological monitoring at the site NUTL1-23 (surface temperature time series illustrating the effect of a thick long-lasting snow cover) at Nordnes, and (c) temperature-depth profile from manual borehole logging of the Bh-S188A borehole in the Bidjovagge study area.

and two pre-IPY holes with continuous thermal monitoring (Kristensen et al., 2008) were included in the observatory (Table 2). Three additional holes were drilled in 2009, two of which were drilled by the local coal-mining company Store Norske Spitsbergen Grubekompani and instrumented in cooperation with TSP NORWAY (Table 2). This gives a total of 17 TSP boreholes with continuous temperature monitoring in Svalbard (Table 1).

The boreholes cover the elevation range from 492 to 990 m a.s.l. in Northern Norway and from 9 to $901 \mathrm{~m}$ a.s.l. in Svalbard (Table 2). The depth of the boreholes ranges from 2.2 to $90 \mathrm{~m}$, although most are 10 to $15 \mathrm{~m}$ deep (Table 2). This gives a total of $570.2 \mathrm{~m}$ of TSP boreholes with ground temperature monitoring in Northern Norway and Svalbard, distributed evenly at the two observatories (281.4 $\mathrm{m}$ in Northern Norway and $288.8 \mathrm{~m}$ in Svalbard, Table 2).

Two of the boreholes in Svalbard and one borehole in Northern Norway were established in collaboration with the PYRN-TSP Nordic project (Table 2). The main objectives of 
Table 2. All NORPERM TSP NORWAY borehole measurement sites, with location, borehole length with temperature data, the start date of monitoring or alternatively the data for manual logging, recording interval in the case of monitoring and type of instrument used. The accuracy of the different instrument types are as follows: YSI-thermistors connected to a Campbell data-logger $\pm 0.05^{\circ} \mathrm{C}$, GeoPrecision $\mathrm{M}-\log 7 \pm 0.2{ }^{\circ} \mathrm{C}, \mathrm{HOBO} \mathrm{U} 22 \pm 0.2{ }^{\circ} \mathrm{C}$, Tinytag $\pm 0.2^{\circ} \mathrm{C}$, EBA thermistor-string connected to Lakewood data-logger $\pm 0.2{ }^{\circ} \mathrm{C}$. The TCN- and SWQS-probes have accuracies of \pm 0.5 and $\pm 0.02^{\circ} \mathrm{C}$, respectively. The accuracy of the manual readings with multimeter is assumed to be $\pm 0.1^{\circ} \mathrm{C}$.

\begin{tabular}{|c|c|c|c|c|c|c|c|c|c|}
\hline $\begin{array}{l}\text { Measurement site } \\
\text { (Borehole name) }\end{array}$ & Borehole ID & Study area & Longitude & Latitude & $\begin{array}{l}\text { Elevation } \\
\text { (ma.s.1.) }\end{array}$ & $\begin{array}{l}\text { Borehole } \\
\text { length }(\mathrm{m}) \\
\text { with } \\
\text { temperature } \\
\text { recording }\end{array}$ & $\begin{array}{l}\text { Start date/ } \\
\text { Log date }\end{array}$ & $\begin{array}{l}\text { Recording } \\
\text { interval (h) }\end{array}$ & Instrument type \\
\hline \multicolumn{10}{|l|}{ Northern Norway } \\
\hline Kistefjellet & Ki-B-1 & Kistefjellet & $18^{\circ} 07^{\prime} 49^{\prime \prime} \mathrm{E}$ & $69^{\circ} 17^{\prime} 27^{\prime \prime} \mathrm{N}$ & 990 & 24.8 & 26-Sep-07 & 6 & YSI therm., Campbell log. \\
\hline Nordnes 1 & No-B-1 & Nordnes & $20^{\circ} 24^{\prime} 33^{\prime \prime} \mathrm{E}$ & $69^{\circ} 33^{\prime} 21^{\prime \prime} \mathrm{N}$ & 624 & 2.3 & $17-$ Sep-08 & 1 & GeoPrecision M-Log7 \\
\hline Nordnes 2 & No-B-2 & Nordnes & $20^{\circ} 25^{\prime} 11^{\prime \prime} \mathrm{E}$ & $69^{\circ} 33^{\prime} 21^{\prime \prime} \mathrm{N}$ & 797 & 2.3 & $17-$ Sep-08 & 1 & GeoPrecision M-Log7 \\
\hline Nordnes 3 & No-B-3 & Nordnes & $20^{\circ} 26^{\prime} 02^{\prime \prime} \mathrm{E}$ & $69^{\circ} 33^{\prime} 26^{\prime \prime} \mathrm{N}$ & 908 & 2.2 & 17-Sep-08 & 1 & GeoPrecision M-Log7 \\
\hline Lavkavagge 1 & La-B-1 & Lavkavagge & $20^{\circ} 26^{\prime} 44^{\prime \prime} \mathrm{E}$ & $69^{\circ} 14^{\prime} 57^{\prime \prime} \mathrm{N}$ & 766 & 14 & 08-Sep-07 & 6 & YSI therm., Campbell log. \\
\hline Lavkavagge 2 & La-B-2 & Lavkavagge & $20^{\circ} 29^{\prime} 34^{\prime \prime} \mathrm{E}$ & $69^{\circ} 14^{\prime} 20^{\prime \prime} \mathrm{N}$ & 600 & 30.5 & 16-Aug-07 & 2 & HOBO U22 \\
\hline Lavkavagge 3 & La-B-3 & Lavkavagge & $20^{\circ} 34^{\prime} 47^{\prime \prime} \mathrm{E}$ & $69^{\circ} 13^{\prime} 26^{\prime \prime} \mathrm{N}$ & 492 & 15.8 & 16-Aug-07 & 2 & НОВО U22 \\
\hline Guolasjavri $1^{*}$ & Gu-B-1 & Guolasjavri & $21^{\circ} 12^{\prime} 38^{\prime \prime} \mathrm{E}$ & $69^{\circ} 21^{\prime} 13^{\prime \prime} \mathrm{N}$ & 786 & 32.3 & 06-Sep-07 & $4-6$ & GeoPrecision M-Log7 \\
\hline Guolasjavri 2 & Gu-B-2 & Guolasjavri & $21^{\circ} 10^{\prime} 05^{\prime \prime} \mathrm{E}$ & $69^{\circ} 21^{\prime} 56^{\prime \prime} \mathrm{N}$ & 814 & 10.5 & 17-Aug-07 & 2 & HOBO U22 \\
\hline Guolasjavri 3 & Gu-B-3 & Guolasjavri & $21^{\circ} 03^{\prime} 39^{\prime \prime} \mathrm{E}$ & $69^{\circ} 21^{\prime} 20^{\prime \prime} \mathrm{N}$ & 780 & 10.5 & 17-Aug-07 & 2 & HOBO U22 \\
\hline Iškoras 1 & Is-B-1 & Karasjok/Iškoras & $25^{\circ} 20^{\prime} 11^{\prime \prime} \mathrm{E}$ & $69^{\circ} 18^{\prime} 08^{\prime \prime} \mathrm{N}$ & 585 & 10.7 & 04-Mar-08 & 6 & YSI therm., Campbell log. \\
\hline Iškoras $2^{* *}$ & Is-B-2 & Karasjok/Iškoras & $25^{\circ} 20^{\prime} 45^{\prime \prime} \mathrm{E}$ & $69^{\circ} 18^{\prime} 02^{\prime \prime} \mathrm{N}$ & 600 & 58.5 & 26-Sep-08 & 6 & YSI therm., Campbell log. \\
\hline Abojavri 1 & Ab-B-1 & Abojavri & $22^{\circ} 11^{\prime} 38^{\prime \prime} \mathrm{E}$ & $69^{\circ} 38^{\prime} 33^{\prime \prime} \mathrm{N}$ & 761 & 6.6 & 19-Aug-07 & 2 & НОВо U22 \\
\hline Abojavri 2 & Ab-B-2 & Abojavri & $22^{\circ} 07^{\prime} 33^{\prime \prime} \mathrm{E}$ & $69^{\circ} 40^{\prime} 51^{\prime \prime} \mathrm{N}$ & 570 & 30.3 & 19-Aug-07 & 2 & HOBO U22 \\
\hline Trolltinden* & Tr-B-1 & Trolltinden & $20^{\circ} 25^{\prime} 54^{\prime \prime} \mathrm{E}$ & $70^{\circ} 04^{\prime} 30^{\prime \prime} \mathrm{N}$ & 848 & 29.4 & Logger failure & - & GeoPrecision M-Log7 \\
\hline Bidjovagge $^{a}$ & Bh-S188A & Bidjovagge & $22^{\circ} 29^{\prime} 54^{\prime \prime} \mathrm{E}$ & $69^{\circ} 16^{\prime} 23^{\prime \prime} \mathrm{N}$ & 607 & 22.0 & Aug-07 & - & therm., multimeter \\
\hline Bidjovagge $6^{\mathrm{a}}$ & Dh-06 & Bidjovagge & $22^{\circ} 28^{\prime} 50^{\prime \prime} \mathrm{E}$ & $69^{\circ} 17^{\prime} 59^{\prime \prime} \mathrm{N}$ & 732 & 22.0 & Aug-07 & - & therm., multimeter \\
\hline \multirow[t]{3}{*}{ Tana Gruber $^{\mathrm{a}}$} & GA01-04 & Tana/Rustefjelbma & $28^{\circ} 31^{\prime} 49^{\prime \prime} \mathrm{E}$ & $70^{\circ} 28^{\prime} 37^{\prime \prime} \mathrm{N}$ & 370 & 22.0 & Aug-07 & - & therm., multimeter \\
\hline & & & & & $\begin{array}{l}\text { Total length } \\
\text { with monitoring }\end{array}$ & 281.4 & & & \\
\hline & & & & & $\begin{array}{l}\text { Total length with } \\
\text { manual logging }\end{array}$ & 66.0 & & & \\
\hline \multicolumn{10}{|l|}{ Svalbard } \\
\hline Kapp Linnè 1 & KL-B-1 & Kapp Linnè & $13^{\circ} 38^{\prime} 05^{\prime \prime} \mathrm{E}$ & $78^{\circ} 03^{\prime} 21^{\prime \prime} \mathrm{N}$ & 20 & 29 & 22-Sep-08 & 6 & YSI therm., Campbell log. \\
\hline Kapp Linnè 2 & KL-B-2 & Kapp Linnè & $13^{\circ} 38^{\prime} 13^{\prime \prime} \mathrm{E}$ & $78^{\circ} 03^{\prime} 15^{\prime \prime} \mathrm{N}$ & 20 & 38 & $22-$ Sep-08 & 6 & YSI therm., Campbell log. \\
\hline Kapp Linnè 3 & KL-B-3 & Kapp Linnè & $13^{\circ} 38^{\prime} 23^{\prime \prime} \mathrm{E}$ & $78^{\circ} 03^{\prime} 11^{\prime \prime} \mathrm{N}$ & 20 & 4 & 19-Aug-08 & 1 & GeoPrecision M-Log7 \\
\hline Kapp Linnè snow drift & KL-B-4 & Kapp Linnè & $13^{\circ} 44^{\prime} 27^{\prime \prime} \mathrm{E}$ & $78^{\circ} 03^{\prime} 26^{\prime \prime} \mathrm{N}$ & 44 & 2.8 & 08-Aug-09 & 1 & Tinytag, Gemini data-loggers \\
\hline Ny-Ålesund & NA-B-1 & Ny-Ålesund & $11^{\circ} 55^{\prime} 54^{\prime \prime} \mathrm{E}$ & $78^{\circ} 55^{\prime} 19^{\prime \prime} \mathrm{N}$ & 46 & 9.9 & 06-Aug-08 & 1 & GeoPrecision M-Log7 \\
\hline Gruvefjellet $^{* * *}$ & GF-B-1 & Advent- and Longyeardalen & $15^{\circ} 37^{\prime} 55^{\prime \prime} \mathrm{E}$ & $78^{\circ} 11^{\prime} 48^{\prime \prime} \mathrm{N}$ & 464 & 5 & 03-Mar-08 & 1 & YSI therm., Campbell log. \\
\hline Endalen $^{* *, * * * *}$ & EN-B-1 & Advent- and Longyeardalen & $15^{\circ} 46^{\prime} 54^{\prime \prime} \mathrm{E}$ & $78^{\circ} 11^{\prime} 26^{\prime \prime} \mathrm{N}$ & 53 & 19 & $16-$ Sep-08 & 6 & YSI therm., Campbell log. \\
\hline Old Auroral Station $1^{*}$ & AS-B-1 & Advent- and Longyeardalen & $15^{\circ} 50^{\prime} 05^{\prime \prime} \mathrm{E}$ & $78^{\circ} 12^{\prime} 05^{\prime \prime} \mathrm{N}$ & 9 & 9.5 & $23-\mathrm{Feb}-04$ & 1 & Tinytag, Gemini data-loggers \\
\hline Old Auroral Station $2^{* *}$ & AS-B-2 & Advent- and Longyeardalen & $15^{\circ} 50^{\prime} 05^{\prime \prime} \mathrm{E}$ & $78^{\circ} 12^{\prime} 05^{\prime \prime} \mathrm{N}$ & 9 & 9.9 & 16-Sep-08 & 1 & GeoPrecision M-Log7 \\
\hline Snow drift 1 & SN-B-1 & Advent- and Longyeardalen & $15^{\circ} 54^{\prime} 48^{\prime \prime} \mathrm{E}$ & $78^{\circ} 11^{\prime} 15^{\prime \prime} \mathrm{N}$ & 10 & 9.7 & 30-Jul-08 & 1 & GeoPrecision M-Log7 \\
\hline Snow drift 2 & SN-B-2 & Advent- and Longyeardalen & $15^{\circ} 54^{\prime} 48^{\prime \prime} \mathrm{E}$ & $78^{\circ} 11^{\prime} 15^{\prime \prime} \mathrm{N}$ & 10 & 5 & 02-Dec-08 & 1 & GeoPrecision M-Log7 \\
\hline Innerhytte pingo & IP-B-1 & Advent- and Longyeardalen & $16^{\circ} 20^{\prime} 39^{\prime \prime} \mathrm{E}$ & $78^{\circ} 11^{\prime} 20^{\prime \prime} \mathrm{N}$ & 84 & 19 & 03-May-08 & 1 & GeoPrecision M-Log7 \\
\hline Longyearbyen school & SK-B-1 & Advent- and Longyeardalen & $15^{\circ} 36^{\prime} 23^{\prime \prime} \mathrm{E}$ & $78^{\circ} 12^{\prime} 32^{\prime \prime} \mathrm{N}$ & 68 & 9 & $29-\mathrm{Feb}-08$ & 1 & GeoPrecision M-Log7 \\
\hline Larsbreen & LB-B-1 & Advent- and Longyeardalen & $15^{\circ} 35^{\prime} 54^{\prime \prime} \mathrm{E}$ & $78^{\circ} 11^{\prime} 33^{\prime \prime} \mathrm{N}$ & 208 & 11 & 08-May-08 & 1 & GeoPrecision M-Log7 \\
\hline Breinosa $^{* * * * *}$ & E-2009 & Advent- and Longyeardalen & $16^{\circ} 04^{\prime} 01^{\prime \prime} \mathrm{E}$ & $78^{\circ} 08^{\prime} 35^{\prime \prime} \mathrm{N}$ & 677 & 10 & 10-Mar-09 & 1 & GeoPrecision M-Log7 \\
\hline Lunckefjell $^{* * * *}$ & $20-2009$ & Lunckefjell & $16^{\circ} 46^{\prime} 09^{\prime \prime} \mathrm{E}$ & $78^{\circ} 01^{\prime} 16^{\prime \prime} \mathrm{N}$ & 901 & 90 & 22-Jun-09 & 24 & YSI therm., Campbell log. \\
\hline Svea 5 & Sv-B-5 & Svea & $16^{\circ} 47^{\prime} 42^{\prime \prime} \mathrm{E}$ & $77^{\circ} 52^{\prime} 54^{\prime \prime} \mathrm{N}$ & 20 & 8 & 03-Apr-05 & $2-6$ & EBA therm., Lakewood log. \\
\hline Dh1-CO2- $07^{\mathrm{b}, * * * * *}$ & Dh1-CO2-07 & Advent- and Longyeardalen & $15^{\circ} 32^{\prime} 48^{\prime \prime} \mathrm{E}$ & $78^{\circ} 14^{\prime} 10^{\prime \prime} \mathrm{N}$ & 5 & 440.0 & 06-Dec-07 & - & SWQS water quality probe \\
\hline $\mathrm{Dh} 2-\mathrm{CO} 2-07^{\mathrm{b}, * * * * * *}$ & Dh2-CO2-07 & Advent- and Longyeardalen & $15^{\circ} 32^{\prime} 44^{\prime \prime} \mathrm{E}$ & $78^{\circ} 14^{\prime} 10^{\prime \prime} \mathrm{N}$ & 5 & 440.2 & 04-Dec-07 & - & SWQS water quality probe \\
\hline \multirow[t]{3}{*}{ Dh4-CO2- $09^{\mathrm{c}, * * * * * *}$} & Dh4-CO2-07 & Advent- and Longyeardalen & $15^{\circ} 49^{\prime} 25^{\prime \prime} \mathrm{E}$ & $78^{\circ} 12^{\prime} 09^{\prime \prime} \mathrm{N}$ & 9 & 900.5 & 02-Dec-09 & - & TCN-probe \\
\hline & & & & & $\begin{array}{l}\text { Total length } \\
\text { with monitoring }\end{array}$ & 288.8 & & & \\
\hline & & & & & $\begin{array}{l}\text { Total length with } \\
\text { manual logging }\end{array}$ & 1780.7 & & & \\
\hline
\end{tabular}

${ }^{*}$ Pre-IPY data available.

** Partly or fully sponsored by the PYRN-TSP project.

*** Near real-time data access.

${ }^{* * * *}$ Made in cooperation with Store Norske Spitsbergen Grubekompani.

***** Logging made by the Longyearbyen $\mathrm{CO}_{2}$ Lab research project and data made available for TSP NORWAY.

a Only manual logging, recorded with thermistor-string and multimeter.

b Only manual logging, recorded with SWQS-probe.

c Only manual logging, recorded with TCN-probe. 
the PYRN-TSP project were to complement the TSP NORWAY borehole network in Northern Norway and Svalbard and to extend it into northern Sweden (five holes) and northern Finland (one hole) (Juliussen et al., 2008; Christiansen et al., 2010), and to provide capacity building of young permafrost scientists. NORPERM will be the main database also for the PYRN-TSP project, although the map service of the graphical user interface so far only covers Norway and Svalbard.

Two types of instrumentation are used for continuous temperature monitoring in boreholes; miniature temperature data-loggers and thermistor-strings connected to Campbell dataloggers (Table 2). Miniature temperature data-loggers (GeoPrecision, Tinytag, Hobo U22 and U23, UTL-1) generally have lower accuracies $\left(0.2\right.$ to $\left.0.27^{\circ} \mathrm{C}\right)$ than the Campbell-logger set-ups $\left(<0.05^{\circ} \mathrm{C}\right)$, but allow more widespread use of this less expensive instrumentation. The equipment has been calibrated at $0^{\circ} \mathrm{C}$ in an ice-bath prior to installation. Two of the boreholes (the $19 \mathrm{~m}$ deep Endalen hole and the $5 \mathrm{~m}$ deep Gruvefjellet hole) have been additionally instrumented for near real-time data transfer via GSM, and the latest data can be accessed and directly downloaded via an URL-address provided in the metadata fact sheets. This has been of great value both for TSP NORWAY research, education and outreach efforts. The temperature recording interval is $1-6 \mathrm{~h}$, but $24 \mathrm{~h}$ for the deepest hole (Table 2). The time series covers at present one to three hydrological years, i.e. the IPY period (Table 2).

Manual temperature logging has been made in cooperation with the Geological Survey of Norway in three holes drilled in 2007 and 2009 as part of the research project Longyearbyen $\mathrm{CO}_{2} \mathrm{Lab}$ (http://co2-ccs.unis.no/) and in three old exploration boreholes in Northern Norway (Table 1). The holes in Svalbard were logged to 440 to $900 \mathrm{~m}$ (Table 2) using two types of probes measuring geophysical parameters. The first probe, the TCN-probe, measures temperature with an accuracy of $0.5^{\circ} \mathrm{C}$, electrical conductivity and natural gamma radiation. The water quality probe (SWQS) measures temperature with a high accuracy of $0.02{ }^{\circ} \mathrm{C}$, electrical conductivity, pressure, degree of saturation, $\mathrm{Ph}$, redox potential and nitrogen content. For both probes the measurements are reliable only in liquid water, so the measurements were made immediately after drilling before the drilling fluid froze. Thus, these probes give data that are not strictly reflecting the temperature in the permafrost. For the old holes in Northern Norway it was not possible to use these probes, so they were logged to only $22 \mathrm{~m}$ with a thermistor-string that was read with a multimeter (Table 2).

Temperature is monitored in the air, snow cover, at the ground surface and/or in the upper layer of the ground $(<2 \mathrm{~m})$ to study the effect of meteorological and micrometeorological factors on the ground temperature. There are 52 such set-ups in Svalbard, including mainly pre-IPY sites that have been included into the Nordenskiöld Permafrost Observatory, and 46 sites established during the
IPY in Northern Norway (Table 1). Miniature temperature data-loggers of different types have been used, but primarily from the same manufacturers as for the borehole miniloggers (Tinytag, GeoPrecision M-Log, HOBO U22 and U23, UTL1 , with accuracies of 0.2 to $0.27^{\circ} \mathrm{C}$ ). The temperature recording interval is $1-2 \mathrm{~h}$. Ground temperatures are obtained either on relatively snow-free sites to achieve a good relationship to air temperature, or below thick snow covers to obtain values on the Basal Temperature of the winter Snow cover (BTS) (Haeberli, 1973).

Ground temperature data are also being monitored by three high-schools in southern Norway through the TSP NORWAY education and outreach module TSP-fryseboksen; the TSP-freezer. The TSP-freezer is a box containing a frost tube and a $1.0 \mathrm{~m}$ long thermistor string with three thermistors connected to a GeoPrecision miniature data-logger. The schools bought the box from TSP NORWAY and installed the frost tube and thermistor-string to monitor depth of seasonal frost in their schoolyards, or on nearby mountain tops where permafrost is expected. The Longyearbyen school borehole in Svalbard is also part of the education and outreach module, and is also part of the Permafrost Health Outreach Program of the University of Alaska, Fairbanks (http://www.uaf.edu/water/projects/permafrost/top.htm).

Also the research project Permafrost and seasonal frost in southern Norway: Understanding and modeling the atmosphere-ground temperature (CRYOLINK) (Etzelmüller et al., 2009) started during the IPY, however, focusing geographically on southern Norway. CRYOLINK collects permafrost and seasonal frozen ground temperature data from altitudinal transects in the mountain areas Juvvass (6 boreholes), Jetta ( 3 boreholes) and Tron ( 3 boreholes), to delineate the local altitudinal limit and thermal state of permafrost.

\section{Data quality}

The data in NORPERM are raw, except for the Campbell logger data which are automatically corrected by the logger according to the ice-bath calibration to achieve the $0.05^{\circ} \mathrm{C}$ accuracy. Also, obvious erroneous recordings (spikes) are manually removed by the data provider or the administrator before the data series are published. It was chosen to publish the raw data along with the ice-bath calibration results instead of publishing corrected data as this is more transparent to the end users.

Ice-bath calibration were made on the thermistor-strings before instrumentation and will be repeated regularly for long-term monitoring sites to ensure high-quality data. Unfortunately, the calibration data was not saved in the beginning. It was just checked against the accuracy given by the manufacturer ( 2 thermistorstrings). A new ice-bath calibration should soon be made for the long-term installations with the coarser $0.2^{\circ} \mathrm{C}$ accuracy, and these will all be provided in NORPERM. For the older installations no ice-bath 
calibrations are available. In-borehole calibration by the use of two thermistorstrings, of which one was to be calibrated and the second was used as reference, was made for three sites in Northern Norway. All calibration data can be found in the individual borehole metadata fact sheets. Between the ice-bath calibrations, zero-curtain calibration provides a possibility for evaluating data quality from the near-surface loggers.

The administrator is responsible for the overall data quality and to ensure that all TSP NORWAY data and other relevant data are included in NORPERM.

\section{The design of NORPERM}

On 26 February 2009 the NORPERM database was officially launched as the main data legacy of the TSP NORWAY IPYproject. Prior to this, all permafrost data were stored only locally by individual scientists. NORPERM fulfils the criteria set by the IPY data policy by providing open, free and full access to all temperature data acquired by the project and gradually also to other data on ground temperature in Norway.

The Geological Survey of Norway (NGU) is the managing institution for geological data in Norway, and is therefore the natural institution to host a Norwegian ground temperature database. NORPERM was developed as part of the larger NGU borehole database system. The database and its graphical user interface were designed in close collaboration between NGU IT-technicians and TSP NORWAY scientists, with a TSP NORWAY post doc scientist acting as database administrator during the development and first operational phase. The technical programming was made by IT-technicians at NGU, specialized on relational databases and online and map-based graphical user interfaces, respectively.

The design process started with identification of the data types to be included in the database; Temperature data series acquired in the air, snow cover, near ground surface or boreholes by monitoring set-ups, but also temperature profiles with depth acquired by occasional manual borehole logging (cf. Fig. 4). NGU has temperature logs from deep boreholes $(<1000 \mathrm{~m})$ from projects on crustal heat generation and heat flow (Pascal et al., 2008; Slagstad et al., 2009) that also should be included. These are, however, not from permafrost areas. The database should also hold metadata and photographs for detailed site description.

Important criteria had to be defined and a suitable database structure developed before the technical development commenced. NORPERM should be easy to use by the different scientists despite large amounts of data in different formats and being measured with different instruments, and it should have a map-based interface. Another criterion was that proper citation of the datasets when used by other scientists should be ensured. This was facilitated through a ci-

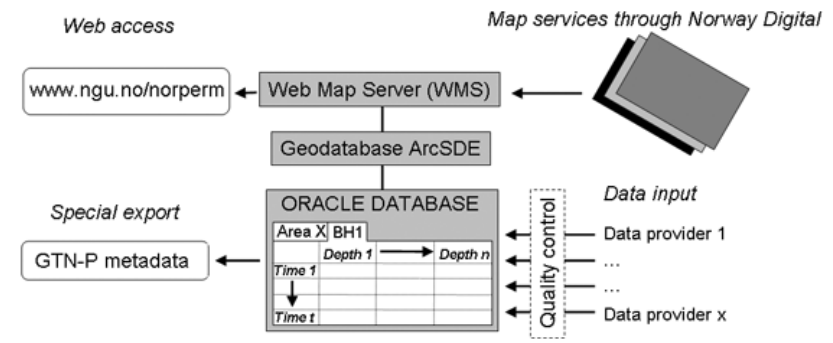

Figure 5. NORPERM data management structure. Data is entered and stored in an Oracle database (RDBMS) module. The GTN-P metadata export is also developed in Oracle. The data is georeferenced and made available online through a map-based user interface based on WMS technology. Digital map services (layers) for the background map are available through Norway Digital.

tation template, following the IPYDIS policy on citation of IPY datasets. This template can be found under the Information about the data tag in NORPERM. The design process lasted two years, from the start of IPY in March 2007 until the launch at the end of the IPY in February 2009.

\subsection{Technical design}

The NGU database system is built on the Oracle Database relational database management system (RDBMS) and Oracle development tools (Oracle Forms, Oracle Reports, PL/SQL etc). The core of NORPERM, the relational database containing the temperature data, was therefore also developed in the same software environment (Fig. 5). Some technical modules are common for the entire or parts of the NGU database system, such as login routines, part of the borehole metadata description and handling of photographs. Other modules, such as import of temperature data from diverse formats had to be developed. Oracle maintenance strategies are followed and technical maintenance including back-up every night is performed by the IT-section at NGU, securing all the data in an organized and professional way.

The Oracle interface for data import and maintenance is web-based and password-restricted, enabling external data management by the data providers. The administrator, who is a permafrost scientist, can sit outside NGU and create or delete NORPERM user profiles for data providers, and grant access privileges to/from the users through the NGU database system. The users can be given reading, writing or administration privileges depending on their different roles.

The data comes in two fundamentally different formats; the time series of temperatures from various depths and the temperature profiles from manual borehole logging with depth (cf. Fig. 4). The two types of data must be handled differently in the database, with different routines for import, export and storage. In addition, the use of different instruments and data-logger software has resulted in a wide variety of data formats (in particular date formats) that is handled 

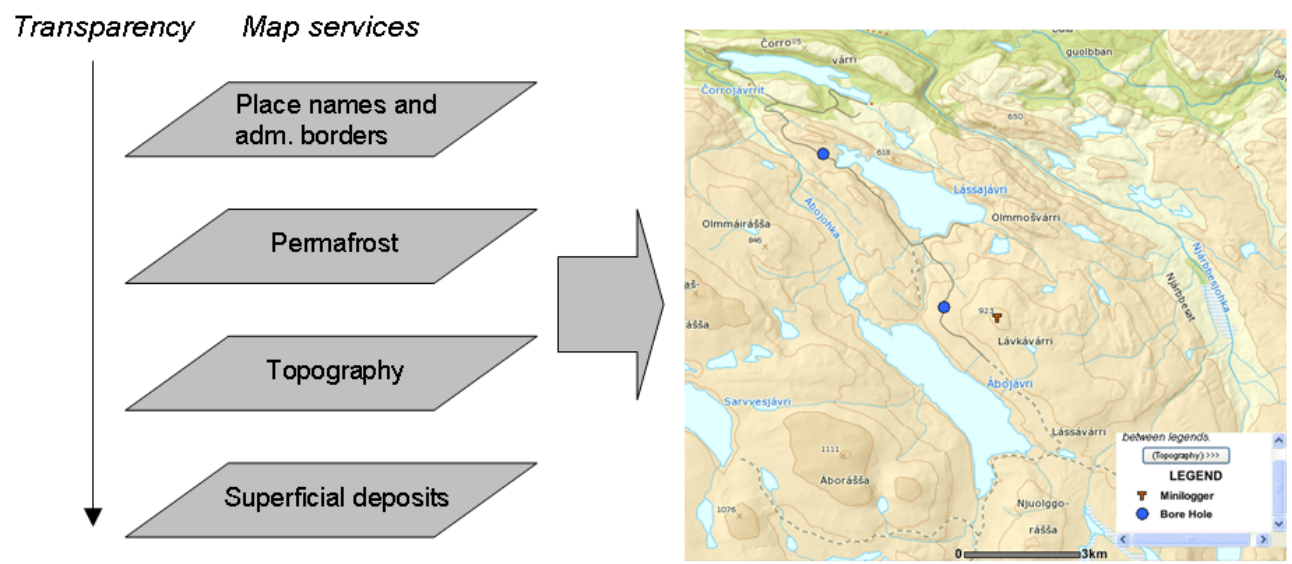

Figure 6. Compilation of different map layers from different vendors into a composite map. Transparency can be set by the user for the individual map services. The permafrost Map service is the georeferenced data from the Oracle module. The map shows the Abojavri study area with topography and place names.

by the import routine. The export function, however, gives a standard text-file that can be read by most spread sheets.

To make the data available through a map-based public user interface, they are georeferenced in an ArcSDE geodatabase and made available on the internet using Web Map Service (WMS, www.isotc211.org) technology (Fig. 5). WMS makes it possible to combine geographic information (map services) from various sources in Norway, and share it between many users and applications. In practice, the map services from different service providers comprise the whole map, and are overlaid in an ordered succession on the screen (Fig. 6). Transparency can be set by the user for the individual map services to obtain the desired map view. Map services used in NORPERM are topography, orthophotos and superficial deposits, the latter only for mainland Norway. These are shared through the public national co-operation on digital data, Norge Digital (Norway Digital, www.norgedigitalt.no). Map service providers are The Norwegian Mapping Authority, the Norwegian Polar Institute and NGU. The applications include standard facilities such as zooming and panoraming.

\subsection{Structural design}

The NORPERM database is structured into four levels at different spatial scales (Fig. 7). At the uppermost level are the entire land areas of Norway and Svalbard, as the database shall be able to contain data from all parts of the entire geographical area of the Norwegian Kingdom. This is represented in the graphical user interface as the full extent of the map services. Mainly because of differences in available background maps, but also because of the distance between the two land areas, there are separate user interfaces for Norway and Svalbard (www.ngu/no/norperm). The second level is the permafrost observatories (Figs. 1, 2, 3) followed by the study areas at the third level, and finally the individual measurement sites at the finest level of detail (Fig. 7).

The permafrost observatories are at the regional scale, with the Nordenskiöld Land Permafrost Observatory in Svalbard covering $5000 \mathrm{~km}^{2}$, and the North Scandinavian Permafrost Observatory covering $75000 \mathrm{~km}^{2}$ in Northern Norway. At this scale the study areas are given in point format on the map (Fig. 7).

A study area represents a geographically limited area within an observatory where one or more measurement sites are clustered (Fig. 7). Spatially a study area is typically at the scale of a mountain or a valley. The study areas vary in geographical extent from, in the case of only one measurement site, the immediate surroundings of the site, to $30 \mathrm{~km}$ or more in length as for the Advent- and Longyeardalen study area in Svalbard with 13 boreholes and 42 miniature temperature data-loggers (Table 1). Metadata describing the study area, such as climate, large-scale geomorphology and geology, is given in fact sheets for each area (cf. Fig. 8). The fact sheet appears when clicking the study areas in the map. The metadata are complemented with overview photographs and sketch maps in standard JPEG-format.

When zooming to a scale finer than 1:1000000, the map view changes to show point symbols for the individual measurement sites (Fig. 7). A measurement site may be a borehole with temperature monitoring or a manual temperature log, or measurements of air-, snow-, and near ground-surface temperatures from miniature temperature data-loggers (MTDs). Most sites have been given ID according to if it is a borehole or MTD site. For example, for the site IS-B-1 the -B-indicates that this is a borehole, and the prefix IS is an abbreviation for the site name, in this case Iškoras. Similarly, the -M- in RW-M-1 indicates that this is a miniature temperature datalogger. The two data types are displayed with different symbols in the map (Fig. 7). Each 

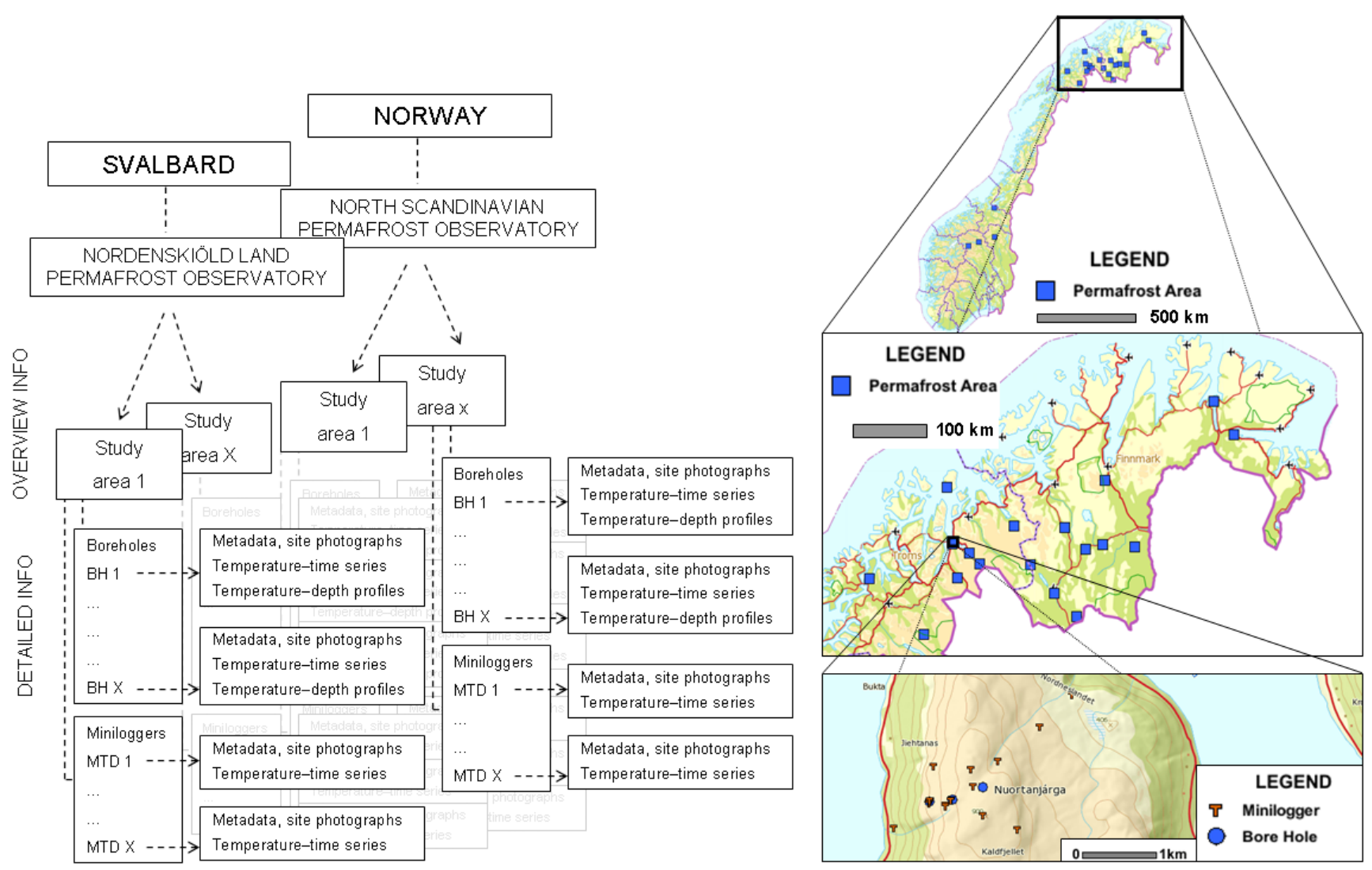

Figure 7. Overview of the structure of NORPERM. The database is structured into four levels with decreasing spatial scale, represented by the entire land areas of Svalbard and Norway at the coarsest scale, the two permafrost observatories at the regional scale followed by the study areas and finally the measurement sites at the finest level of detail. The insert maps shows how this is displayed in the map, with to the upper right the entire Norwegian land area with study areas shown as point symbols, in the middle right the North Scandinavian Permafrost Observatory with permafrost areas also here shown as point symbols, and to the lower right the Nordnes study area with the measurement sites shown as point symbols.

measurement site has a fact sheet with metadata following the GTN-P standard (Burgess et al., 2000) along with information on instrument type and calibration (Fig. 8). Photographs showing site details are provided at this level. All the temperature data series from the respective measurement sites are available through links in the fact sheet. All data series must be homogenous, i.e. recorded with the same instrument and have the same recording interval throughout. If one or both of these are changed, or if there is a significant period without data coverage, the data are stored as separate series. One measurement site may thus have several data series, and there is a link for each of the data series. The fact sheet also gives a link to an automatically generated graphical overview plot for each of the data series.

\section{NORPERM metadata exports}

Reporting of metadata and annual data summaries to the GTN-P, the international TSP metadatabase, is handled with an export routine of the relational database that automatically fills out the GTN-P metadata form on the administrator's request (Fig. 5) and stores it in digital format. The temperature at the depth of the zero annual amplitude or lower thermistor is automatically extracted and included in the GTN-P form. The form is sent by e-mail to the GTN-P office at the Geological Survey of Canada. Further, borehole metadata have been made available for the Svalbard Science Forum Research in Svalbard metadatabase for cross-disciplinary IPY metadata search. 


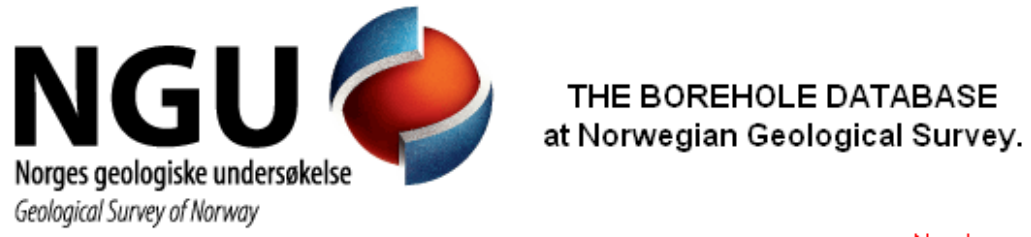

\section{Fact Sheet for borehole}

Name on Borehole : Kistefjellet; Borehole ID : Ki-B-1

Area : Kistefjell

Climatic zone : Nordland og Troms

Land :Norway

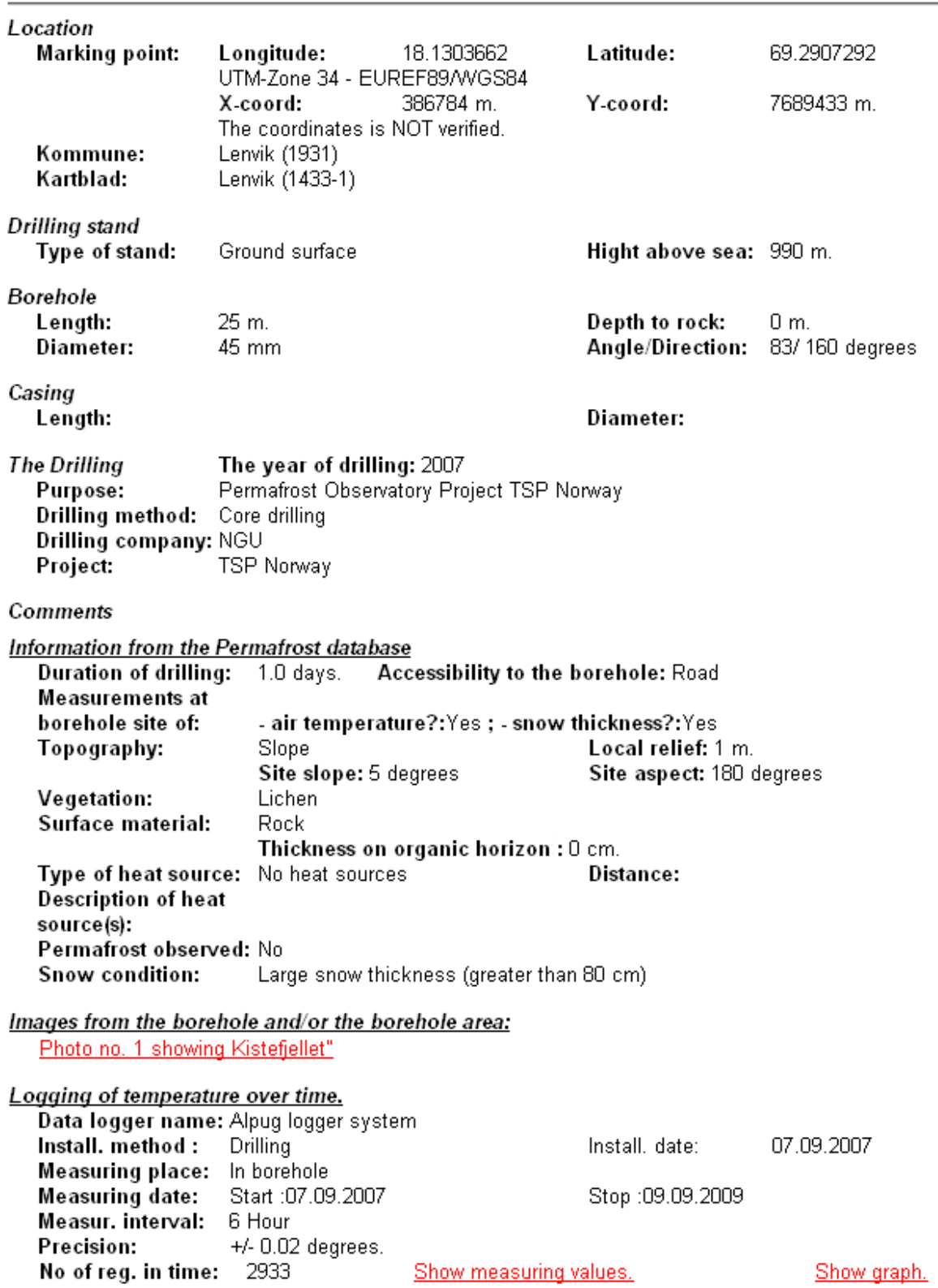

Figure 8. Example of a borehole fact sheet for the Kistefjellet (KI-B-1) borehole. 


\section{Possible future NORPERM developments}

To increase the scientific value of NORPERM, we will work to include also all relevant permafrost temperature data from Norway and Svalbard collected before IPY. Much of such data is at the moment being imported into the database, but it does require an effort also in the post-IPY future to ensure that all relevant data is included.

In its present state, the graphical user interface of NORPERM has somewhat reduced functionality on search functions. At present it is possible to make geographical searches (place names, municipality and county) in the mainland Norway application. We hope to be able to develop search functions also on study areas, measurement site names and IDs and metadata describing the sites. A metadata search option would enable a search for all sites with a specific parameter value, e.g. boreholes in bedrock. A search option on temperature summaries at standard levels (annual temperature in the air, at the ground surface and at a specified depth in the ground, in particular at the depth of the zero annual temperature amplitude) would also be feasible.

A possibility for improved visualization through introducing 3D view has been discussed for the entire NGU database system, and NORPERM will follow this possible upgrade.

We have had increased Nordic permafrost collaboration during IPY, and particularly with the PYRN-TSP project collecting permafrost borehole temperatures in Finland, Norway and Sweden. Therefore it would be natural to expand NORPERM to cover the entire Nordic area, thus further developing it to become a regional Nordic permafrost database, still to be abbreviated NORPERM. Such a Nordic Permafrost Database will provide a much better permafrost data overview and basis for collaboration than has ever existed in the Nordic area. A Nordic coverage is already implemented in the relational database, but the limitation is the lack of suitable map services for the graphical user interface. A Nordic Permafrost Database would be the first regional permafrost database providing completely open and free access to all permafrost data from an entire region, and with access to near real-time data from selected boreholes.

Acknowledgements. Special thanks go to the Geological Survey of Norway for excellent cooperation on this challenge. Many thanks also to all our TSP NORWAY colleagues for inspiring discussions on the TSP data and the database structure. We have developed NORPERM especially for you and your future students and colleagues to ensure the legacy of all our permafrost data as collected at the end of the fourth International Polar Year in 2009, and thus hope you will enjoy using it in the future. We also thank the reviewers for their constructive comments that improved the manuscript.

Edited by: O. Eisen

\section{References}

Åhman, R.: Palsar i NordNorge, Meddelanden från Lunds Universitets Geografiska Institution Avhandlingar LXXVIII, 1977 (in Swedish).

Brown, J., Nelson, F. E., and Hinkel, K. M.: The circumpolar active layer monitoring (CALM) program research design and initial results, Polar Geography, 3, 165-258, 2000.

Brown, J., Ferrians, O. J., Heginbottom, J. A., and Melnikov, E. S.: Circum-Arctic map of permafrost and ground-ice conditions, Boulder, CO, National Snow and Ice Data Center/World Data Center for Glaciology, Digital Media, 1998, Revised: February 2001.

Brown, J. and Christiansen, H. H.: Report from the International Permafrost Association, Permafrost Periglac., 17, 377379, 2006.

Burgess, M. M., Smith, S. L., Brown, J., Romanovsky, V., and Hinkel, K.: Global Terrestrial Network for Permafrost (GTNetP): permafrost monitoring contributing to global climate observations. Current Research, Geological Survey of Canada, 2000E14, 8 pp., 2000.

Christiansen, H. H.: Thermal Regime of Ice-wedge Cracking in Adventdalen, Svalbard, Permafrost Periglac., 16, 87-98, 2005.

Christiansen, H. H., Etzelmüller, B., Isaksen, K. Juliussen, H., Farbrot, H., Humlum, O., Johansson, M., Ingeman-Nielsen, T., Kristensen, L., Hjort, J., Holmlund, P., Sannel, A. B. K., Sigsgaard, C., Åkerman, H. J., Foged, N., Blikra, L. H., Pernosky, M. A., and Ødegård, R.: The Thermal State of Permafrost in the Nordic area during IPY 2007-2009, Permafrost Periglac., 21, 156-181, 2010.

Etzelmüller, B., Berthling, I., and Sollid, J. L.: Aspects and Concepts on the Geomorphological Significance of Holocene Permafrost in Southern Norway, Geomorphology, 52, 87-104, 2003.

Etzelmüller, B., Humlum, O., Isaksen, K., Schuler, T., Skaugen, T., Ødegård, R. S., Farbrot, H., and Hipp, T.: CRYOLINK Permafrost and seasonal frost in Norway, European Geosciences Union, General Assembly, Abstract EGU2009-3589, 2009.

Farbrot, H., Isaksen, K., and Etzelmüller, B.: Present and Past Distribution of Mountain Permafrost in Gaissane Mountains, Northern Norway, in: Proceedings Volume 1, Ninth International Conference on Permafrost, University of Alaska Fairbanks, 29 June3 July 2008, edited by: Kane, D. L. and Hinkel, K. M., Institute of Northern Engineering, University of Alaska Fairbanks, 427432, 2008 .

Gruber, S. and Haeberli, W.: Permafrost in steep bedrock slopes and its temperature-related destabilization following climate change, J. Geophys. Res., 112, F02S18, doi:10.1029/2006JF000547, 2007.

Haeberli, W.: Die Basis Temperatur der winterlichen Schneedecke als möglicher Indikator für die Verbreitung von Permafrost, Zeitschrift für Gletscherkunde und Glazialgeologie, 9, 221-227, 1973.

Harris, C., Arenson, L. U., Christiansen, H. H., Etzelmüller, B., Frauenfelder, R., Gruber, S., Haeberli, W., Hauck, C., Hoelzle, M., Humlum, O., Isaksen, K., Kääb, A., Kern-Lütschg, M. A., Lehning, M., Matsuoka, N., Murton, J. B., Noetzli, J., Phillips, M., Ross, N., Seppäla, M., Springman, S. M., and Vonder Mühll, D.: Permafrost and climate in Europe: Monitoring and modelling thermal, geomorphological and geotechnical responses, Earth- 
Sci. Rev., 92, 117-171, 2009.

Heggem, E. S. F., Juliussen, H., and Etzelmüller, B.: Mountain permafrost in central-eastern Norway, Norsk Geogr. Tidsskr., 59, 94-108, 2005.

Humlum, O., Instanes, A., and Sollid, J. L.: Permafrost in Svalbard: a review of research history, climatic background and engineering challenges, Polar Res., 22, 191-215, 2003.

Isaksen, K., Holmlund, P., Sollid, J. L., and Harris, C.: Three deep alpine permafrost boreholes in Svalbard and Scandinavia, Permafrost Periglac., 12, 13-25, 2001.

Isaksen, K., Hauck, C., Gudevang, E., Ødegård, R. S., and Sollid, J. L.: Mountain permafrost distribution in Dovrefjell and Jotunheimen, southern Norway, based on BTS and DC resistivity tomography data, Norsk Geogr. Tidsskr., 56, 122-136, 2002.

Isaksen, K., Blikra, L. H., Eiken, T., and Sollid, J. L.: Mountain permafrost and instability of rock slopes in western and northern Norway, Abstracts Volume, PACE21 Field Workshop, Longyearbyen, Svalbard, 8-13 September 2004, p. 32, 2004.

Isaksen, K., Sollid, J. L., Holmlund, P., and Harris, C.: Recent warming of mountain permafrost in Svalbard and Scandinavia, J. Geophys. Res.-Earth, 112, F02S04, doi:10.1029/2006JF000522, 2007.

Isaksen, K., Farbrot, H., Blikra, L. H., Johansen, B., Sollid, J. L., and Eiken, T.: Five-Year Ground Surface Temperature Measurements in Finnmark, Northern Norway, in: Proceedings of the Ninth International Conference on Permafrost, Fairbanks, Alaska, 789-794, 2008.

Jorgenson, M. T., Shur, Y. L., and Pullman, E. R.: Abrupt Increase in Permafrost Degardation in Arctic Alaska, Geophys. Res. Lett., 33, L02503, doi:10.1029/2005GL024960, 2006.

Juliussen, H. and Humlum, O.: Towards a TTOP ground temperature model for mountainous terrain in central-eastern Norway, Permafrost Periglac., 18(2), 161-184, 2007.

Juliussen, H. and Humlum, O.: Thermal regime of openwork block fields on the mountains Elgåhogna and Sølen, central-eastern Norway, Permafrost Periglac., 19, 1-18, 2008.

Juliussen, H., Johansson, M., Hjort, J., and Isaksen, K.: PYRNTSP: Permafrost Young Researchers Network's Contribution to the Thermal State of Permafrost Project in the Nordic countries, 33th International Geological Congress, Oslo, 6-14 Aug 2008, Abstract 2008 1345051, 2008.

Kristensen, L., Christiansen, H. H., and Caline, F.: Temperatures in coastal permafrost in the Svea area, Svalbard, in: Proceeedings of the Ninth International Conference on Permafrost, Fairbanks, Alaska, 1005-1010, 2008.

Lachenbruch, A. L., Cladouhos, T. T., and Saltus, R. W.: Permafrost temperature and the changing climate, Proceedings of the Fifth International Conference on Permafrost, Trondheim, Norway, 917, 1988.
Nelson, F. E., Anisimov, O., and Shiklomanov, N. I.: Subsidence risk from thawing permafrost, Nature, 410, 889-890, 2001.

Osterkamp, T. E. and Romanovsky, V. E.: Evidence for Warming and Thawing of Discontinuous Permafrost in Alaska, Permafrost Periglac., 10, 17-37, 1999.

Osterkamp, T. E.: Characteristics of the recent warming of permafrost in Alaska, J. Geophys. Res.-Earth, 112, F02S02, doi:10.1029/2006JF000578, 2007.

Pascal, C., Barrére, C., Davidsen, B., Ebbing, J., Elvebakk, H., Gernigon, L., Olesen, O., Roberts, D., Siedlecka, A., Skilbrei, J. R., Slagstad, T., and Wissing, B.: HeatBar Report 2008, Basement Heat Generation and Heat Flow in the western Barents Sea - Importance for Hydrocarbon Systems, Geological Survey of Norway, Report no. 2008.072, 64 pp., 2008.

Pavlov, A. V.: Current Changes of Climate and Permafrost in the Arctic and Sub-Arctic of Russia, Permafrost Periglac., 5, 101110, 1994.

Schuur, E. A. G., Vogel, J. G., Crummer, K. G., Lee, H., Sickman, J. O., and Osterkamp, T. E.: The effect of permafrost thaw on old carbon release and net carbon exchange from tundra, Nature, 459, 556-559, 2009.

Slagstad, T., Balling, N., Elvebakk, H., Midttømme, K., Olesen, O., Olsen, L., and Pascal, C.: Heat-flow measurements in Late Palaeoproterozoic to Permian geological provinces in south and central Norway and a new heat-flow map of Fennoscandia and the Norwegian-Greenland Sea, Tectonophysics, 473, 341-361, 2009.

Smith, S. L., Burgess, M. M., Riseborough, D., and Nixon, F. M.: Recent trends from Canadian permafrost thermal monitoring network sites, Permafrost Periglac., 16, 19-30, 2005.

Sollid, J. L., Isaksen, K., Eiken, T., and Ødegård, R. S.: The transition zone of mountain permafrost on Dovrefjell, southern Norway, in: Proceedings (Vol. 2) of the Eight International Conference on Permafrost, Zurich, Switzerland, 21-25 July, edited by: Phillips, M., Springmann, S. M., and Arenson, L. U., Swets \& Zeitlinger, Lisse, 1085-1090, 2003.

van Everdingen, R. O.: Multi-language glossary of permafrost and related ground-ice terms. International Permafrost Association, University of Calgary, Calgary, 1998.

Zhang, T., Barry, R. G., Knowles, K., Hegginbottom, J. A., and Brown, J.: Statistics and Characteristics of Permafrost and Ground-Ice Distribution in the Northern Hemisphere, Polar Geography, 23, 132-154, 1999. 